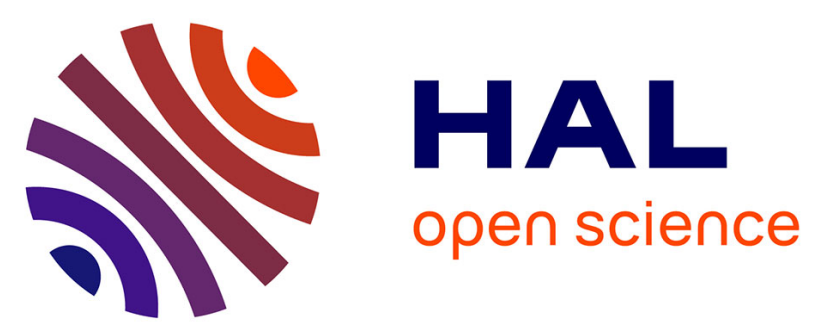

\title{
Quantitative image based analysis of endocrine disruptor effects on mitochondria morphology-function in prostate cancer cells.
}

Aurélie Charazac, Célia Decondé Le Butor, Mamadou Gueye, Jérôme Gilleron, Kévin Giuletti, Maeva Gesson, Patrick Fénichel, Xavier Descombes, Frédéric Bost, Stéphan Clavel, et al.

\section{To cite this version:}

Aurélie Charazac, Célia Decondé Le Butor, Mamadou Gueye, Jérôme Gilleron, Kévin Giuletti, et al.. Quantitative image based analysis of endocrine disruptor effects on mitochondria morphology-function in prostate cancer cells.. Signalife, May 2017, Nice, France. pp.1. hal-01548770

\author{
HAL Id: hal-01548770 \\ https://hal.science/hal-01548770
}

Submitted on 28 Jun 2017

HAL is a multi-disciplinary open access archive for the deposit and dissemination of scientific research documents, whether they are published or not. The documents may come from teaching and research institutions in France or abroad, or from public or private research centers.
L'archive ouverte pluridisciplinaire HAL, est destinée au dépôt et à la diffusion de documents scientifiques de niveau recherche, publiés ou non, émanant des établissements d'enseignement et de recherche français ou étrangers, des laboratoires publics ou privés. 


\section{in prostate cancer cells.}

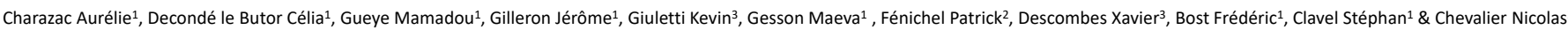
1) Institut National de la Santé et de la Recherche Médicale (INSERM) UMR U1065/UNS, Centre Méditerranéen de Médecine Moléculaire (C3M), 062020 Nice cedex 3, France

2) Centre Hospitalier 3) INRIA CRI-SAM, 2004 route des Lucioles, 06902, Sophia Antipolis Cedex, France

\section{Endocrine disruptors}

According to the World Health Organization, an endocrine disruptors may be describe as an exogenous substance or mixture that alters function(s) of the endocrine system and consequently causes adverse health effects in an intact organism or its progeny, or (sub) populations.

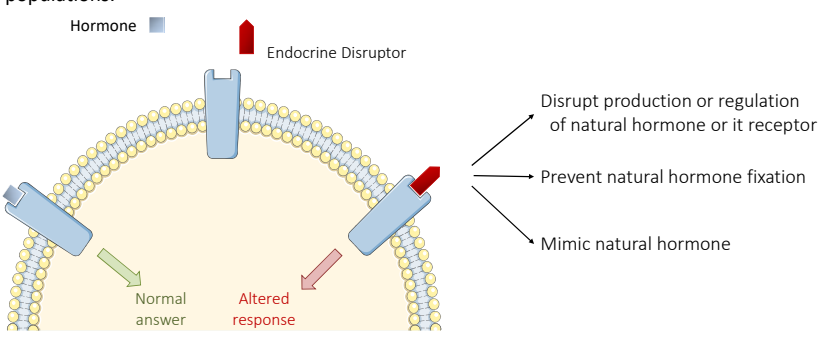

They are found in many everyday products like food packaging, food preservatives or additives, pesticides residues, everyday plastic objects, etc.

Widely distributed throughout the environment and bioaccumulable in living organisms, Persistent Organic Pollutants are a specific class of EDC that accumulate in fat deposit. Some of them have been recognized as causing adverse effects on wildlife and also human's health such as diabetes and cancer..

\section{Working hypothesis}

Cancer cells undergo of genetic modifications that lead to a phenotype characterized by a high metabolic flexibility allowing them to grow in various cellular environments and favoring their proliferative and invasive capacities as well as death resistance. Mitochondria are complex organelles possessing a central role in metabolism, apoptosis, signaling, etc.

\section{AIM}

Develop screening procedures to analyze the effects of various endocrine disruptors at different concentrations and in combination on:

$\longrightarrow$ Mitochondrial morpho-function (Hight throughput screening + image analysis and classification)

\section{$\longrightarrow$ Metabolism (XF analyzer, SeaHorse) \\ $\longrightarrow$ Migration/Invasion/Proliferation \\ (Videomicroscopy, IncuCyte) \\ $\longrightarrow$ Signaling pathways}

(Luminex)

\section{Workflow for microscopy} based screening

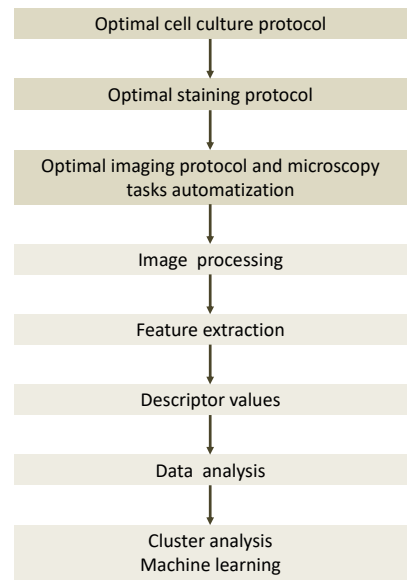

Microscopy based analysis of mitochondria functional parameters

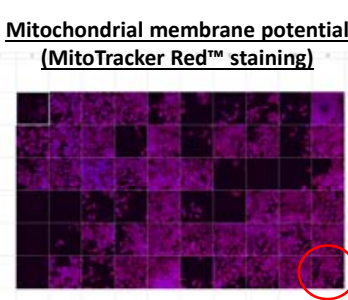

Image of a 96 wells plate (20X, Nikon A1R, automatization process)

Superoxide anion production (MitoSox ${ }^{\mathrm{TM}}$ staining)

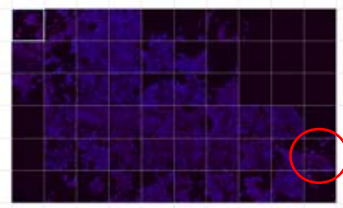

Image of a 96 wells plate

(20X, Nikon A1R, automatization process)
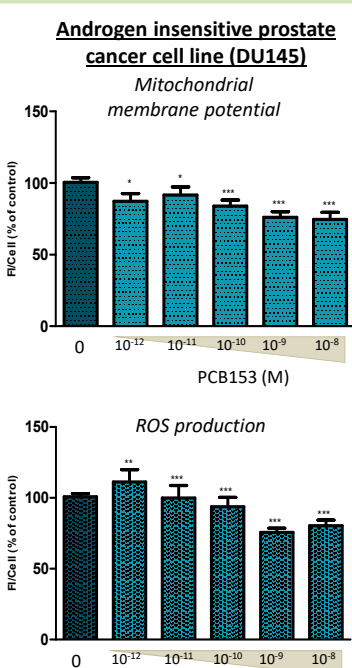

PCB153 (M)

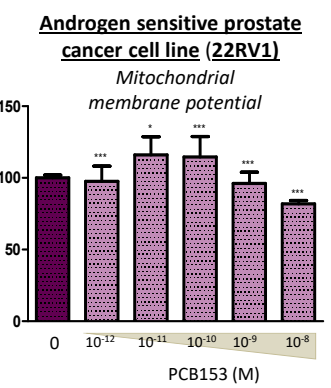

ROS production

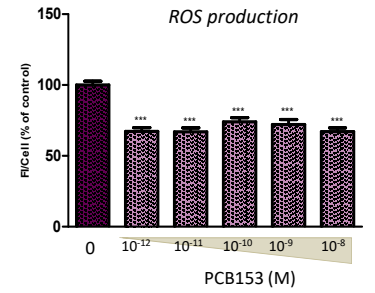

PCB153 (M)

Exemple of results obtained using this quantitative image based analysis on DU145 and 22RV1 prostate cancer cell lines after treatment with a range doses of PCB153, an ED non inflammable electric isolant.

Mitochondrial topology analysis and classification

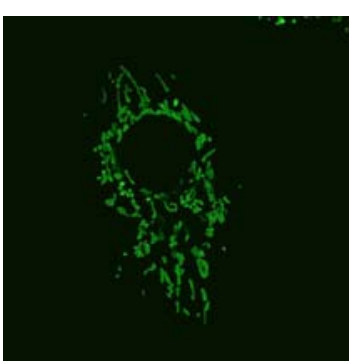

Original picture (60X, Nikon A1R)

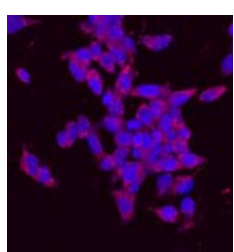

Magnification 20X

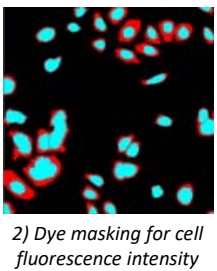

analysis

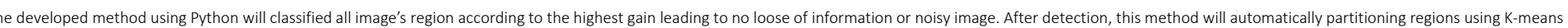
methods leading to the clusters classifications thanks to following criterias : form, compactness, size, elongation, fragmentation.

When combined, morphological and functional parameters allow us to discriminate subtle perturbations of the mitochondrial structurefunction induced by endocrine disruptors in prostate cancer cells. We are confident that this multiparameter analysis strategy could represent a new perspective in identification and characterization of endocrine disruptors based on their effects on cell metabolism in order to estimate their potential risk on human health. In the future, this can lead to a high-throughput screening method useful to industrial and regulatory agencies.
Don't hesitate to contact us for collaboration!

aurelie.charazac@unice.fr 